DOI: https://doi.org/10.24144/2409-6857.2018.2(52).42-48

УДК 504.064

Готра В.B.

\title{
СУТНІСТЬ ТА ОСОБЛИВОСТІ ІНТЕГРАЦЙНИХ ПРОЦЕСІВ ЯК ЧИННИКА РОЗВИТКУ НАЦІОНАЛЬНОЇ ЕКОНОМІКИ
}

\begin{abstract}
У статті систематизовано та досліджено підходи, щзодо сутності інтеграційного економічного процесу. Належну увагу приділено сочіально-економічній його складовій. Запропоновано сутнісне розуміння ,інтеграційного економічного процесу”, як об'єднання держав, внаслідок обмеженості природних, трудових та фінансових ресурсів в иій чи іншій крайні для створення товарів та послуг, щзо $\epsilon$ конкурентоспроможними на ичих ринках та подоланні кризових явищ в краӥнах, а саме зубожіння народів, безробіття, падіння курсу національних валют, щуо веде до сочіальних проблем циих крайн.
\end{abstract}

Ключові слова: інтеграчійний економічний процес, інтеграчія, типи міжнародної економічної інтеграції, економічна інтеграція, інтеграційні угрупування, ефективний економічний організм, вертикальна та горизонтальна інтеграчія.

Постановка проблеми. За останні півстоліття поняття «інтеграція» стало невід'ємною частиною економічної категорії у світовій політиці і міжнародних відносинах. У центрі уваги опиняються такі суттєві проблеми сучасності, як забезпечення безконфліктного співіснування держав і розвиток ефективного співробітництва, функції і доля сучасної держави i взаємодія політики та економіки. Процеси інтеграції розглядаються як позитивні, з огляду на їхню здатність вирішити всі ці проблемні питання.

Аналіз останніх досліджень і публікацій. Серед фахівців, на сьогоднішній день немає однозначності щодо визначення терміна інтеграція. В економічній науці існує думка, що в основі інтеграції $\epsilon$ економічні процеси, які розвиваються на основі інтернаціоналізації всього суспільного життя що прискорюється науково-технічним прогресом, зростання взаємозалежності народів i держав. Дану проблематику досліджували наступні вчені: Ю.Шишков, як закономірний процес, який $\epsilon$ наслідком поступового відкриття країн одна одною, М.Ходжес, який вважає, що інтеграція це формування нової політичної системи 3 існуючих до цього розділених систем. Також значну увагу дефініції терміну інтеграція приділяли Е.Хаас, К. Дойч, Б.Баласс, Е.Гааз, У. Уоллас.

Формулювання цілей статті. Мета статті здійснити аналіз теоретичних питань i практичного застосування різних підходів щодо сутності та особливостей світових інтеграційних

(C) Готра Вікторія Вікторівна, д.е.н., доц., професор кафедри економіки та підприємництва ДВНЗ «Ужгородський національний університет», м. Ужгород, тел.+380506280171,email: viktoriya.hotra@uzhnu.edu.ua процесів як чинника розвитку національної економіки.

Опис основного матеріалу дослідження. Процес європейської інтеграції ще надовго залишиться найяскравішим прикладом глибини інтеграційних процесів у сучасному світі. Не зменшуючи значення культурно-асиміляційних тенденцій або невпинної глобалізації світової економіки, неможливо не визнати, що саме європейські політико-інтеграційні досягнення $€$ найбільш успішним інтеграційним трендом зламу тисячоліть. Попри періодичну появу проблемних ситуацій (економічного, політичного i, навіть, особистісного спрямування), які пригальмовують інтеграційні процеси, євроінтеграційний вектор жодного разу не змінив напрямок, що дає підстави констатувати неухильне зростання якості інтеграційної співпраці. Цей процес має дві очевидні складові. По-перше, Єдиний європейський акт започаткував період поступового послаблення повноважень держав членів у процесі прийняття рішень у ЄС. Подруге, список спільних європейських політик неухильно розширюється і лише у небагатьох із них (освітня, сімейна, меншою мірою - соціальна) національні уряди зберігають суттєвий люфт для застосування владного ресурсу.

Незважаючи на те, що у буквальному значенні поняття «інтеграція» означає отримання цілого 3 певних частин, (походження 3 латинського integration - відновлення і цілий) як поступове зближення та об'єднання економічних суб'єктів у процесі їх взаємодії (взаємовпливу, взаємопроникнення, взаємозбагачення та ін). Економічна інтеграція - це процес зближення i поступового об'єднання національних економічних систем, сучасна найрозвинутіша форма інтернаціоналізації господарського життя, зокрема продуктивних сил, техніко-економічних, 
організаційно-економічних, виробничих відносин і господарського механізму.

Зарубіжний дослідник Ю. Шишков вважає, що на інтеграцію певний вплив мають процеси міжнародного поділу праці, торгівлі та інші економічні відносини на макро- та макрорівні. У своїй публікації «Формування європейського простору» він відзначає, що інтеграція - «це закономірний процес, який $€$ наслідком поступового відкриття країн одна одною, під час якого декілька багато державних макроекономічних організмів крок за кроком зрощуються в цілий полі державний господарський простір, який із часом структурується в новий, укрупнений, більш ефективний економічний організм» $[1,834]$.

Поза тим у класичному визначенні, яке дається неофукціоналістом Е.Хаасом, під інтеграцією розуміється «процес, за допомогою лояльності політичних акторів кількох національних утворень змішується в бік нового наднаціонального центру прийняття рішень, який стає центром політичної активності. Кінцевим результатом процесу політичної інтеграції є нове політичне співтовариство» $[1,819]$.

Безліч інших визначень $€$ ще більш нечіткими. Наприклад, М.Ходжес вважає, що інтеграція - це «формування нової політичної системи 3 існуючих до цього розділених систем». Представник комунікативного підходу К.Дойч розуміє інтеграцію як «створення спільноти безпеки між державами певного регіону». За визначенням У. Уолласа, інтеграція - це «створення і підтримка інтенсивних і різнобічних систем взаємодії між раніше автономними частинами» $[1$, с. 821$]$.

Існує також дискусія щодо розуміння інтеграції як процесу та інтеграції як результату. Окрім того, існують розбіжності 3 приводу питання, що $\epsilon$ рушійною силою інтеграції: економічна вигода чи політична ідея. Єдине, що об'єднує всі теорії - це згода в тому, що предметом їх вивчення є мирне і технологічне обгрунтоване об'єднання незалежних держав, які усвідомлюють свою взаємозалежність, у єдину систему.

Тенденційне прагнення України до все більшого розширення інтеграційних зв'язків загальносвітового господарського простору ставить перед вітчизняною фінансовоекономічною наукою ряд надзвичайно актуальних завдань, зокрема мова іде про адекватне прогнозування тенденцій інтеграційних процесів та своєчасне визначення ïx впливу на національну економічну систему. Поява міжнародних організацій нового типу Європейських спільнот дала поштовх до їх теоретичної класифікації. Зусилля західних вчених було розроблено біля десятка концепцій інтеграції. 3 найбільш відомих 3'явилася комунікативна теорія (К. Дойч та інші). Вона була побудована на принципі «ізоморфізму» (уподібнення). Це дало йому можливість припускати, що всі соціальні і політичні процеси, зокрема відносини між окремими етнічними спільнотами, політичними націями та державами підпорядковуються ідентичним закономірностям, котрі були логічно виведені кібернетикою, i передусім, таким відомим їі представником, як $\mathrm{H}$. Вінер, К.Дойч визначив і основний показник цих взаємовідносин - обсяг контактів, зв'язків i обміну між їх учасниками. Із цього він зробив досить логічний висновок: зростання обсягу зв'язків між контактуючими учасниками призводить до їх зближення і об'єднання, а при певних умовах і виникнення нової спільноти чи утворення. Показано, що при цьому К.Дойч розглядав народ як велику групу осіб, об'єднаних комунікативними можливостями, тобто можливостями спілкування, а країну як територію i населення, об'єднані «сіткою із потоків комунікацій й транспортних систем». Народи і країни, цілком слушно зауважував він, починають інтегрувати у міру того, як вони стають взаємопов'язаними. Інтеграція, за його твердженням, це переважно розвиток сітки соціальних зв'язків або комунікацій. Внаслідок процесів інтеграції, підкреслює К. Дойч, виникає «суспільство безпеки, тобто «суспільство, в якому існує реальна впевненість у тому, що його члени не будуть вести між собою фізичної боротьби, а будуть вирішувати суперечки іншими шляхами» [6.c.64].

Дещо по іншому трактували процеси інтеграції представники функціональної концепції ( Д.Мітрені, Б. Маліновські, А. Радкліфф -Браун та інші.). Iї̈ засновник, американський соціолог Т. Парсонс, доводив, що процес інтеграції забезпечується діяльністю таких чотирьох підсистем: економічної, яка виконує функції адаптації; політичної, котра визначає цілі та шляхи їх досягнення; нормативної, яка власне і забезпечує інтеграцію та цілісна, що сприяє відтворенню цілісної системи. Для поглиблення процесів інтеграцій на думку, Парсонса, потрібні спеціальні механізми універсальна правова система, розширення прав і привілеїв учасників цього процесу, а також підвищення ролі так званих символічних посередників (грошей, мови, емоцій тощо). Все це призводить до поглиблення процесів інтеграції й виникнення єдиної, цілісної системи, де панують гармонійні, безконфліктні відносини між іiі складовими. [6.c.65]. 
Проміжне становище між комунікативною та функціональною концепціями інтеграції займає неофункціональна концепція професора політології Каліфорнійського університету Е.Гааза. Вона увібрала в себе чимало ідей К. Дойча, Т.Парсона та англійського вченого Д.Мітрені. Для Е.Гааза i його прихильників головне - це процес інтеграції, а не іiї стан чи наслідки, при чому вони вважали, що інтеграція розвивається переважно в економічній царині і тут же поширюється на політику. Неофункціоналісти, передусім, підкреслюють значимість спонукальних мотивів учасників інтеграційних процесів, 3'ясовують пристосованість еліт, їх специфічну роль та стратегічну лінію у цих процесах, досліджують фактори зростання й занепаду об'єднаних спільнот. Е.Гааз, зауважував, якщо сила теорії комунікації в іiі узагальненості й системному характері, то сила неофункціоналізму - в його близькості до учасників інтеграційних процесів[6.c.65].

Американський учений Б.Баласса розглядав інтеграцію як «стан і процес», виокремивши такі етапи інтеграції: зона вільної торгівлі, митний союз, спільний ринок, економічний союз, повна економічна інтеграція. Відповідно до отриманих результатів він зауважив, що об’єднанню країн спричинилася торгівля дуже суттєвих розмірів [7, с.363].

Прихильники ще одного підходу вважають, що створення інтегрованої системи дає змогу ставити спільну мету і спільно іiі досягати (зростання зайнятості, виробництва, соціальна стабільність тощо). За цього збільшуюється роль держави у вирішенні загальних проблем у рамках інтегрованої системи. Представники іншої теорії (П.Робсон, А. Рюгман) вважають, що країни прямують до інтеграції своїх економік з метою подолання „фактора обмеженості” (сировини, інші фактори виробництва). Вважається, що цей фактор сприяв зростанню масштабів виробництва, розвитку товарної диференціації $\mathrm{i}$ нових технологій [7, с.367].

За своєю сутністю інтеграція є категорією, яка відображає процес обміну товарами, послугами, капіталом та робочою силою, що виходить за межі державних кордонів, набуває форм постійного й неухильного зростаючого міжнародного переплетіння національних економік. Вона характеризується насамперед перманентністю темпів зростання світової торгівлі та ВВП в усіх країнах. Проявляється економічна інтеграція в розширенні проникнення компаній в економіку зарубіжних країн за допомогою експорту, а в ширшому значенні - за допомогою іноземних інвестицій у відкриття заводів 3

виробництва

комплектуючих, виробничих підприємств або дочірних підприємств зі збуту продукції. Практично підприємства отримують додаткові можливості для збуту, який стримується через недостатні розміри внутрішнього ринку країни, зменшують свою залежність від єдиного внутрішнього ринку при отриманні прибутку.

Поняття інтеграції використовується у різних галузях науки-політиці, соціології, економіці тощо. У загальному розумінні інтеграцію розглядають в такий спосіб: 1. Відновлення, стан об'єднаності окремих частин та їхніх функцій у єдине ціле [1,c.543]; 2.Об'єднання економічних суб'єктів, поглиблення їхньої взаємодії, розвиток зв'язків між ними, поширення та поглиблення виробничо-технологічних зв'язків, спільне використання ресурсів, об'єднання капіталів [2,с.38]; 3. Процес взаємної адаптації, розширення виробничої та економічної співпраці, об'єднання національних економік двох або більше країн, форма інтернаціоналізації господарського життя [4,c.240]; 4. Розвиток та поглиблення виробничо-технологічних зв'язків, об'єднання капіталів, створення один одному сприятливих умов здійснення економічної діяльності [5,c.543].

Безробіття, падіння курсу національних валют, що веде до соціальних проблем цих країн. Це не що інше як „елітний клуб” по вирішенню даних проблем цих країн. Доцільно підкреслити, що говорячи про силу як вирішальний фактор інтеграції тут ми маємо на увазі не лише: армію, поліцію, зброю, а й економічні та технічні чинники та адміністративні можливості, а також:цінності, символи, ритуали, що має кожна 3 країн, що підлягає інтеграції.

Набуття членства в СОТ, підготовка до підписання Угоди про асоціацію та зону вільної торгівлі між Україною та ЄС, ратифікація угоди про вільну торгівлю $з$ країнами СНД - все це створювало потенційні можливості для забезпечення досягнення цілей збалансованого економічного розвитку держави. Поступове утворення універсального світового середовища ринкової діяльності, що має на меті зниження та скасування державами тарифних та нетарифних регуляторів торгівлі товарами та послугами, лібералізацію руху факторів виробництва та розвиток транснаціональних господарських структуру, виступає наслідком поглиблення багатовекторних процесів інтеграції.

У міжнародній економіці за П. Герстом і Г. Томсоном [3, с.6] виділяється два фундаментальних типи економічної інтеграції. Одним із них - це суто глобальна економіка. Для іншого типу ключовим $є$ обмін між відносно 
незалежними національними економіками, які розвиваються внаслідок зростання внутрішніх суб'єктів господарювання.

У той же час під глобалізацією варто розуміти утворення нової економічної структури, яка „розмиває” національні економічні кордони і в основному базується на функціонуванні транснаціональних економічних угруповань. У глобальній системі економіки окремих держав поглинаються міжнародними процесами, в регулюванні яких національні уряди беруть щоразу менше участі. Натомість сучасною рисою регулювання міжнародної системи є виникнення великих економічних блоків 3 наддержавними міжнародними органами керування і координації економічної діяльності, наприклад, СC, NAFTA. Як показує досвід, всередині таких утворень відбуваються дискримінаційні процеси відносно до слабкіших чи нових учасників. Тому тут важливим $є$ зберегти переваги внутрішнього споживчого ринку.

Другий тип міжнародної економічної інтеграції передбачає розквіт національних економік, використовуючи внутрішні ресурси, та їх входження в міжнародні процеси, зберігаючи національну економічну незалежність, характерні принципи та направленість Прикладом такого напряму міжнародного розвитку $є$ Китай, економіка якого не гармонізована 3 іншими суб'єктами міжнародної діяльності до такого ступеня, як це $\epsilon$ в окремих міжнародних економічних блоках або транснаціональних компаніях, а є відносно закритою економікою, що грунтується на державній формі власності. Показники розвитку економіки Китаю є такими, що якщо їх екстраполювати на 2020 рік, то Китай стане економічно найрозвиненішою країною світу. Це привертає увагу країн 3 перехідною економікою для перейняття досвіду.

В економічній літературі, в діяннях українського уряду акцент у питанні входження України в міжнародний економічний простір, робиться на глобалізаційні процеси. Тобто пропонується перший тип економічної інтеграції i практично не обговорюється альтернативний шлях, який використовується іншими країнами. В останньому випадку такі країни повинні мати критичну кількість компаній, які $є$ конкурентоспроможними на міжнародному ринку i які будуть визначати конкурентні переваги певної країни. Причому ці суб’єкти економічної діяльності повинні бути спроможними самостійно будувати свою діяльність в міжнародному економіко-правовому середовищі, керуючись власними інтересами.

Разом $з$ тим, як зазначається, що Україна, яка за роки незалежності не довела власну здатність створювати умови розширеного та самодостатнього відтворення всіх суб'єктів економічних відносин, в міру входження у світовий економіко-правовий простір та формування національної економіко-правової системи на засадах міжнародних норм і правил „несподівано” перейшла до етапу. Коли питання iii участі та місця в глобалізаційних процесах розглядається вже суто в практичній площині”. [8. c.14-15],

Інтеграція - це складний, багаторівневий процес об'єднання суб'єктів для утворення цілісної системи у різних сферах життєдіяльності суспільства 3 метою розвитку зв'язків та поглиблення взаємодії між ними. Наслідками встановлення тісних торговельних, виробничих та фінансових зв'язків між країнами, поглиблення міжнародного та територіального поділу праці та розвитку спільної системи світового господарства стало становлення однієї із підвидів інтеграції економічної інтеграції.

На нашу думку, економічна інтеграція - це не що інше, як об'єднання держав, внаслідок обмеженості природних, трудових та фінансових ресурсів в цій чи іншій країні для створення товарів, що $\epsilon$ конкурентоспроможними на цих ринках та подоланні кризових явищ в країнах, а саме зубожіння народів. Економічна інтеграція це, процес зближення та взаємодії національних економік держав задля вільного переміщення товарів, послуг, капіталів, робочої сили з метою утворення єдиного економічного простору для здійснення економічної діяльності.

Економічна інтеграція виступає якісно новим етапом розвитку i формою прояву інтернаціоналізації господарського життя та відбувається на рівні національних господарських структур різних держав, а також між підприємствами, фірмами, компаніями, корпораціями. Саме економічна інтеграція проявляється у розширенні i поглибленні виробничо-технологічних зв'язків, спільному використанні ресурсів, об'єднанні капіталів, у створенні сприятливих умов для здійснення економічної діяльності. Економічна інтеграція між країнами виявляється у державних формах економічного об'єднання країн 3 тим чи іншим ступенем узгодження їх національних політик, приклади яких $\epsilon$ : Свропейський Союз, ОПЕК, Світова організація торгівлі, Свропейська асоціація вільної торгівлі тощо.

Особливо помітною останнім часом стає i посилюється тенденція до формування та посилення інтеграційного підходу до регіонального розвитку макросистем, який специфікується природничо-виробничими, функціонально-територіальними та струк- 
турними особливостями систем. Інтеграція стає домінуючим напрямом сучасної економіки, забезпечуючи синергічний ефект у процесі взаємозв'язку і зрощення потенціалів розвитку господарства на всіх рівнях його організації. Необхідність розвитку інтеграційних процесів особливо важлива, в умовах структурної перебудови економіки країни та іiі регіональних структур в єдиному економічному просторі. Посилення й актуалізація інтеграційного процесу макросистем обумовлена необхідністю інтегрування окремих локальних систем у національну і далі світову економіку, модернізації й прискореного їх розвитку та пошуку для цього ресурсів, удосконаленням територіальної організації економічного простору.

Інтегрованість можна розуміти як притаманність макросистеми характеристик, які властиві ii окремим елементам або підсистемам. Такі зв'язки, котрі перетворюють взаємодіючі суб'єкти в єдине ціле, є інтеграцією. Економічна інтеграція передбачає взаємопроникнення та зрощення відтворювальних процесів різних господарських суб'єктів, „у результаті чого незалежні економічні агенти набувають нової властивості вони перетворюються на систему" [9, с.321]. У свою чергу система $є$ сукупністю елементів i зв'язків між ними, яка має властивість не тотожну сумі властивостей іiі елементів.

Інтегрованість можна визначати як стратегічний ресурс, направлений на підвищення ефективності роботи мезо- і макросистем, оптимізацію просторової організації з вектором на входження у світовий економічний простір. Інтеграційний підхід та його реалізація включає зростання потенціалів регіональних господарських систем усіх таксономічних рангів, зниження перешкод для потоків усіх ресурсів i факторів виробництва, модернізацію відтворювальних процесів, зниження рівня диференціації та дезінтеграції регіонального розвитку через інтегральну взаємодію, створення сприятливого життєвого середовища.

Основними характеристиками процесу економічної інтеграції між країнами $\epsilon$ поглиблення економічної співпраці держав, спільне використання науково-дослідного потенціалу на основі міжнародного поділу праці, прискорення науково-технічного прогресу, підвищення ефективності функціонування національних господарств, раціоналізація використання сировинних ресурсів, поглиблення міжнародної спеціалізації виробництва та цілеспрямована перебудова структури національних господарств задля забезпечення вищого ступеня їх взаємодії у світовому госпо- дарському процесі.

Економічна інтеграція відбувається на макрота мікро- рівнях. Макрорівень економічної інтеграції сформувався під впливом процесів глобалізації та регіоналізації. Глобалізація - це процес формування єдиної світової системи світогосподарських зв'язків на основі поглиблення економічних, політичних, соціальних, правових, інформаційних, культурних відносин. Глобалізація передбачає інтернаціоналізацію господарського життя, поширення безпосередніх i опосередкованих зв'язків між суб'єктами економічної діяльності всіх країн світу та утворення міжнародних організацій, таких як: економічні підрозділи ООН (ЕКОСОР, ЮНІДО, ЮНКТАД та ін.), Міжнародний валютний фонд, Світовий банк, Світова організація торгівлі, міжнародні організації в окремих галузях економіки (промисловість, сільське господарство, транспорт). Макрорівень міжнародної економічної інтеграції передбачає ліквідацію будь - яких форм дискримінації торгівельних партнерів та відмінностей між економічними суб' Єктами з метою підвищення ефективності їх економічної діяльності. На мікрорівні вирізняють горизонтальну і вертикальну інтеграцію.

Горизонтальна інтеграція - це інтеграційний процес, що виникає при злитті фірм, які виробляють подібні або однорідні товари з метою їх подальшої реалізації через спільну систему розподілу й отримання за цього додаткового прибутку, і супроводжуються виробництвом за кордоном товарів, аналогічних тим, що виробляються в країні базування.

Вертикальна інтеграція - це процес посилення вертикальних стосунків між споживачем та постачальником шляхом злиття або внутрішнього розвитку, що передбачає об'єднання фірм, які функціонують у різних виробничих циклах. Вертикальна інтеграція суттєво впливає на ефективність діяльності підприємства та конкуренцію на ринку. Різні ступені вертикальних стосунків можуть досягатися використанням кількох організаційних підходів на зразок прямого злиття чи викупу, постійних контрактів та перехресного володіння акціями.

Розрізняють три форми вертикальної інтеграції: інтеграція "вниз" (наприклад, приєднання заводу виробника сировини чи напівфабрикатів до компанії, яка веде головне виробництво); виробнича інтеграція „вгору” (наприклад, придбання сталеплавильною компанією заводу, що виробляє металоконструкції); невиробнича інтеграція „вгору”, що містить сферу розподілу. На певному рівні розвитку мікроінтеграції виникають 
транснаціональні корпорації. Вони є найбільш інтегрованими мікроструктурами.

На міждержавному рівні економічна інтеграція відбувається шляхом формування регіональних економічних об'єднань держав і узгодження їх внутрішньої та зовнішньої економічної політики, що передбачає взаємодію національних економік, створення єдиного економічного простору, розширення торгівельних зв'язків, покращення умов товарообігу, переміщення виробничих ресурсів (капіталу, праці, інформаціі) між державами.

Процес поступального формування спільного ринкового та відтворювального простору географічно, історично та культурно споріднених країн, який супроводжується поглибленням міжнародних зв'язків, уніфікацією умов торговельно-економічної діяльності, зниження та скасування взаємних обмежень 3 метою підвищення економічної ефективності та вирішення глобально-конкурентних завдань на рівні регіонів називається в економічній літературі - регіоналізацією. Регіоналізація є формою глобалізації, оскільки сприяє скасуванню обмежень торгівлі та іншим формам економічної інтеграції.

Процес економічної інтеграції складний i суперечливий. Він обумовлений не тільки економічних, але й політичними причинами, хоча основною причиною інтеграції $\epsilon$ вимоги високорозвинутих факторів виробництва, які переросли рамки національних господарств, історично цей процес складався таким чином, що співвідношення політичних та економічних факторів на окремих етапах змінювалося.

Можна зауважити, що державою для цього концентруються власні механізми регулювання й управління, через які відтворюються потреби та прагнення суспільства. Тому від якості державного механізму й виконання державних функцій залежить стан елементів інтеграційних економічних процесів.

Висновки i перспективи подалыших досліджень. Отже, для створення економічного інтеграційного угрупування двох чи кількох країн необхідні певні політико-правові, економічні, соціально-культурні та інфраструктурні умови. Із політико-правової точки зору принципове значення мають сумісність політичних устроїв та основного законодавства країн, що інтегруються. Ключовими щодо економічних умов інтеграції $\epsilon$ такі критерії: рівень розвитку країн, їх ресурсні та технологічні потенціали; ступінь зрілості ринкових відносин, зокрема національних ринків товарів, послуг, капіталу та праці; масштаби та перспективи розвитку економічних взаємозв'язків країн; важливою $€$ також інфраструктурна та соціально-культурна сумісність. Саме тому процеси формування економічних інтеграційних угруповань країн мають яскраво виражену регіональну специфіку.

Тому основними передумовами утворення інтеграційних процесів $€$ :

1. Схожість рівнів економічного розвитку i ступеня ринкової зрілості країн, що інтегруються. За рідкісним винятком (NAFTA) міждержавна інтеграція відбувається між промислово розвиненими або між країнами, що розвиваються;

2. Географічна наближеність країн, що інтегруються, наявність у більшості випадків спільного кордону та історично сформованих економічних зв'язків;

3. Спільність економічних та інших проблем, що існують перед країнами в області економічного розвитку, фінансування, регулювання економіки, політичного співробітництва тощо. За своєю сутністю економічна інтеграція покликана вирішити низку конкретних проблем, які реально існують перед країнами, що інтегруються;

4. Демонстраційний ефект. У країнах, що належать до інтеграційних утворень, як правило, відбуваються позитивні зміни: прискорення темпів росту, зниження інфляції, ріст зайнятості, що зумовлюють певний психологічний вплив на інші країни.

5. „Ефект доміно”, тобто після того, як більшість країн того чи іншого регіону стали членами інтеграційного об'єднання, інші країни, які залишилися за його межами, відчувають деякі труднощі, що стосуються переорієнтування економічних зв'язків країн, що належать до цього угрупування. Це часто призводить до скорочення обсягів торговельних відносин країн, що залишилися за його межами. У результаті вони змушені вступити в інтеграційне об'єднання. Загалом, зважаючи на зазначені передумови, країни утворюють інтеграційні об'єднання, що незважаючи на їх кількість та різні рівні розвитку, переслідують приблизно однакові цілі.

На світовому рівні інтеграція відбувається шляхом формування міжнародних інтеграційний об'єднань, що обумовлено прагненням країн до підвищення економічної ефективності виробництва. При цьому процес інтеграції носить, перш за все, економічний характер. Однак, у деяких випадках, крім економічних причин, регіональна інтеграція може мати політичні стимули. Зміцнення економічних відносин між країнами, об'єднання національних економік зменшує можливість виникнення політичних конфліктів і дозволяє здійснювати єдину політику щодо інших країн. 


\section{ПЕРЕЛІК ВИКОРИСТАНИХ ДЖЕРЕЛ}

1. Економічна енциклопедія: У трьох томах.Т.1 / Редкол.: С.В. Мочерний та ін.- К.: Видавничий центр „Академія”, 2000 - С.668.

2. Большой энциклопедический словарь: в 2т., Т.1 Гл.ред.А.М. Прохоров.-М.Сов.Энциклопедия, 1991.$1085 \mathrm{c}$.

3. Герст П., Томсон Г. Сумніви в глобалізації. Міжнародна економіка і особливості керування/ П. Герст, Г. Томсон // Пер.з англ.- К.: К.I.С., 2002.- с.6.

4. Международные экономические отношения: [учебн.для вузов]; под. ред.В.Е.Рыбалкина; 9-е издан. перераб. и доп.-М.: ЮНИТИ-ДАНА, 2012.-647с.

5. Управление организацией: Энциклопедический словарь; под ред. Поршнева А.Г., Кибанова А.Я., Гунина В.Н.; 4-е изд.переаб. и доп.-М.: ИНФРА-М, 2009.-822с.

6. 6.Картунов О.В. Вступ до етнопології: наук.-навчальний посібник/ О.В. Картунов.-К.; [б.в], 1999.-С.64.

7. Міжнародна економіка Текст: підручник/ А.П. Румянцева, Г.Н Кличко, В.В. Рокоча та інші; за ред.. А.П. Румянцева.-К.: Знання-Прес,2003.-С.363

8. Україна у Світовій організації торгівлі: очікування та реальні перспективи. Збірник наукових статей.-К.К.: НІСД, 2002.-128, с.14-15.

9. Сторонянська I. Міжрегіональний інституційний розвиток: тенденції і проблеми./ І. СторонянськаЛьвів:ІРД,2011.-321c.

\section{REFERENCES}

1. Ekonomichna entsyklopediya: U tr'okh tomakh.T.1 / Redkol.: S.V. Mochernyy ta in.- K.: Vydavnychyy tsentr „Akademiya”, 2000-S.668.

2. Bolshoy entsyklopedycheskyy slovar: v 2t., T.1 Hl.red.A.M. Prokhorov.-M.Sov.Entsyklopedyya, 1991.-1085c.

3. Herst P., Tomson H. Sumnivy v hlobalizatsiyi. Mizhnarodna ekonomika i osoblyvosti keruvannya/P. Herst,H. Tomson//Per.z anhl.- K.: K.I.S., 2002.- s.6.

4. Mezhdunarodnyye ekonomicheskiye otnosheniya: [uchebn.dlya vuzov]; pod. red.V.Ye.Rybalkina 9-ye izdan. pererab. i dop.-M.: YUNITI-DANA, 2012.-647s.

5. Upravleniye organizatsiyey: Entsiklopedicheskiy slovar; pod red. Porshneva A.G., Kibanova A.YA., Gunina V.N.; 4-ye izd.pereab. i dop.-M.: INFRA-M, 2009.-822s.

6. 6.Kartunov O.V. Vstup do yetnopologiï: nauk.-navchal'niy posíbnik/ O.V. Kartunov.-K.; [b.v], 1999.-S.64.

7. Mizhnarodna ekonomika Tekst: pidruchnyk/ A.P. Rumyantseva, H.N Klychko, V.V. Rokocha ta inshi; za red.A.P.Rumyantseva.-K.: Znannya-Pres,2003.-S.363

8. Ukrayina u Svitoviy orhanizatsiyi torhivli: ochikuvannya ta real'ni perspektyvy. Zbirnyk naukovykh statey.-K.K.: NISD, 2002.-128, s.14-15.

9. Storonyans'ka I. Mizhrehional'nyy instytutsiynyy rozvytok: tendentsiyi i problemy/ I. StoronyanskaLviv:IRD,2011.-321s.

Одержано 02.08.2018 p. 